\title{
The Kornati fire accident facts and figures - configuration, vegetation and meteorology
}

\author{
D. Stipaničev ${ }^{1}$, Z. Šspanjol ${ }^{2}$, M. Vučetić ${ }^{3}$, V. Vučetić ${ }^{3}$, R. Rosavec ${ }^{2}$ \\ $\&$ Lj. Bodrozić ${ }^{1}$ \\ ${ }^{I}$ Faculty of Electrical Engineering, Mechanical Engineering and \\ Naval Architecture, University of Split, Split, Croatia \\ ${ }^{2}$ Faculty of Forestry, University of Zagreb, Zagreb, Croatia \\ ${ }^{3}$ Meteorologycal and Hydrological Service of Croatia, Zagreb, Croatia
}

\begin{abstract}
The biggest fire-fighting accident in the history of fire-fighting in Croatia happened on August 30th 2007. The routine fire-fighting operation ended with 12 dead and one badly injured fire-fighter. In order to understand the Kornati accident the research team was formed and independent scientific investigation performed. The accident was analyzed from meteorological, vegetation, thermodynamics and aerodynamic points of view, and several simulation models of fire propagation were used. The aim of this paper is not only to give introduction to the Kornati accident, describing the input data used in our other Kornati accident analyses, but also to encourage other researchers to perform their own, independent research trying to find the right answer to the question What could have happened on Kornati island on August 30th 2007 between 11:30 and 16:00 hrs? We would like to emphasize that our work on the Kornati accident was dedicated to the Kornati accident victims (A. Crvelin, I. Crvelin, T. Crvelin, A. Juričev, D. Klarić, M. Knežević, J. Lučić, I. Marinović, K. Severdija, G. Skočić, M. Stančić and H. Strikoman) in order to find possible explanations and to prevent similar accidents in the future. We hope that the firefighting service in Croatia will be further improved and that in the future we will be able to predict such dangerous situations.
\end{abstract}

Keywords: forest fire accident, vegetation, meteorology, terrain. 


\section{Introduction}

In summer seasons seven coastal counties in Croatia and in particular the Adriatic islands are permanently exposed from high to very high fire risks, due to densely-spaced conifer forests, very warm climate with low level of humidity and a lot of tourists visiting various costal and islands regions. Because of that Croatia has a long history of organized fire fighting in both, professional and voluntary services and in Croatian fire-fighting history such an accident had never happened before. According to official data, the fire season 2007 belongs to most severe fire seasons. But there is one reason why the fire season 2007 will be particularly remembered in Croatia. On island Kornat in National Park Kornati islands, the routine fire fighting operation ended with 12 dead and one badly injured fire fighter. In order to analyze the Kornati accident in September 2007 the Croatian Parliament and Office for National Security has formed the research team conceived of researchers from various Croatian Universities and Scientific Institutions. Independent scientific investigation was performed; the accident was analyzed from meteorological, vegetation, fire spread, thermodynamics and aerodynamic points of view. Important accident data are described here and more details can be found on http://laris.fesb.hr/kornati2007.

\section{The Kornat accident place}

Island of Kornat is the biggest island among 365 islands in the National Park Kornati islands, quite popular tourist resort in the middle of Croatian Adriatic coast. The accident happened in the Šipnate canyon, the small canyon opened only from the south and surrounded from other three sides by hills Glavica (135 $\mathrm{m}$ - west), Meja (150 m - north) and Veli vrh (212 m - east) shown in Fig. 1 Injured fire-fighters were found on three places, marked with $\mathrm{A}, \mathrm{B}$ and $\mathrm{C}$ in Fig.2. Six were found dead and seven injured. The injuries were very severe, so 17 days after the accident six badly injured fire-fighters passed away. Only one fire-fighter F. Lučić recovered completely.

The fire begins between 11:00 and 11:30 hrs in Vrulje bay $6.6 \mathrm{~km}$ south-east from Šipnate canyon. Fire-fighters came to Kornat by helicopter. The landing place was Glavica hill. Fig. 3 shows inclination angles and slopes of Šipnate canyon. Average canyon slopes in the second canyon part, from the point $b$ to accident place $\mathrm{C}$ is $\mathrm{SLOPE}_{\mathrm{bC}}=15.5 \%$. Important evidences are three trees found on the line of fire spread and shown in Fig.4. Trees were not completely burned, only leafs in their bottom parts were burned. Leafs on the top were dehydrated showing the direction of the hot air flow from south to north. Upper half part of the hill Glavica on the west side of canyon was unburned giving us the possibility to collect appropriate vegetation samples.

\section{Vegetation}

Century-long pasture, production of lime and feeling of trees for torches are the main reason for degradation of vegetation of Kornati islands. According to the 


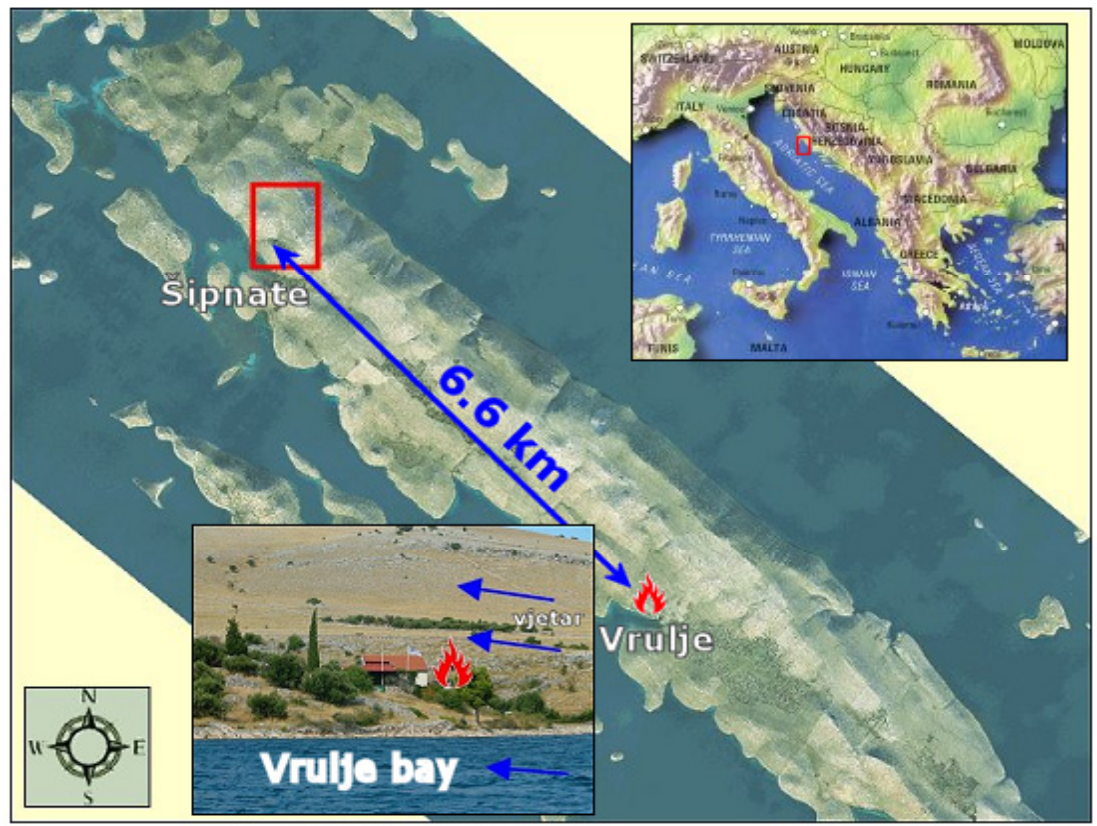

Figure 1: Ignition point and the place of accident.

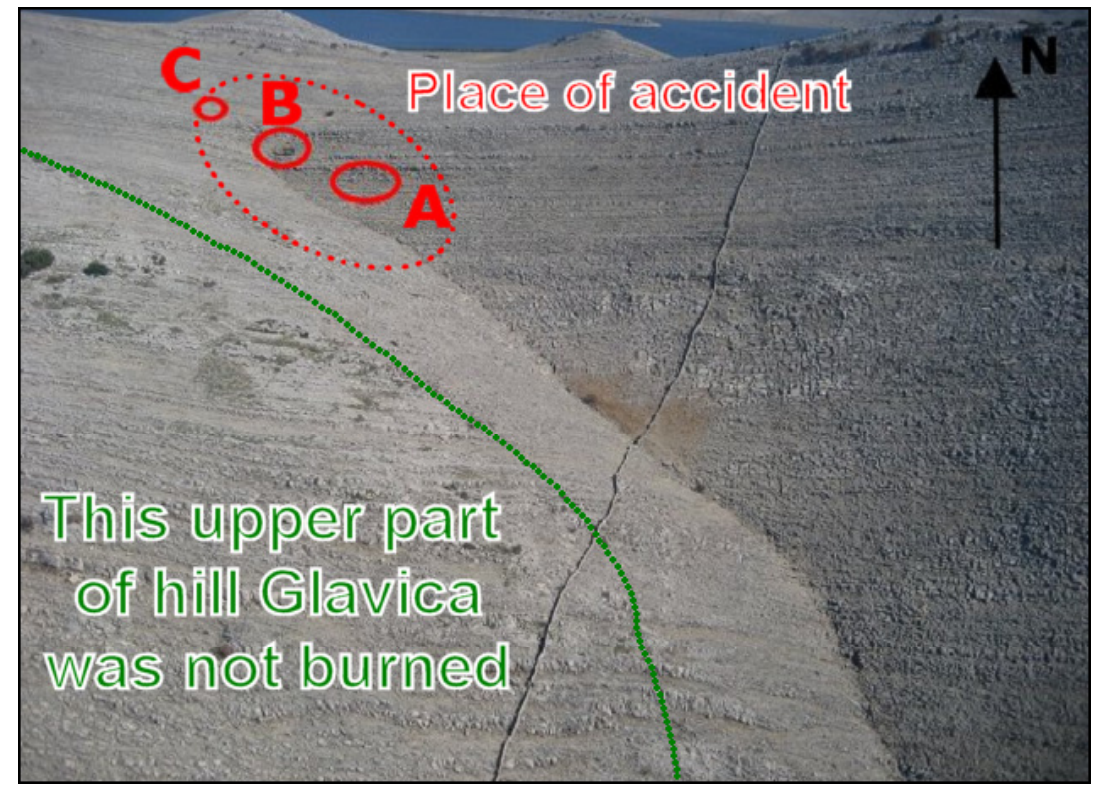

Figure 2: Air photo of Šipnate canyon with marked places where firefighters were found. Upper part of hill Glavica was not burned. 


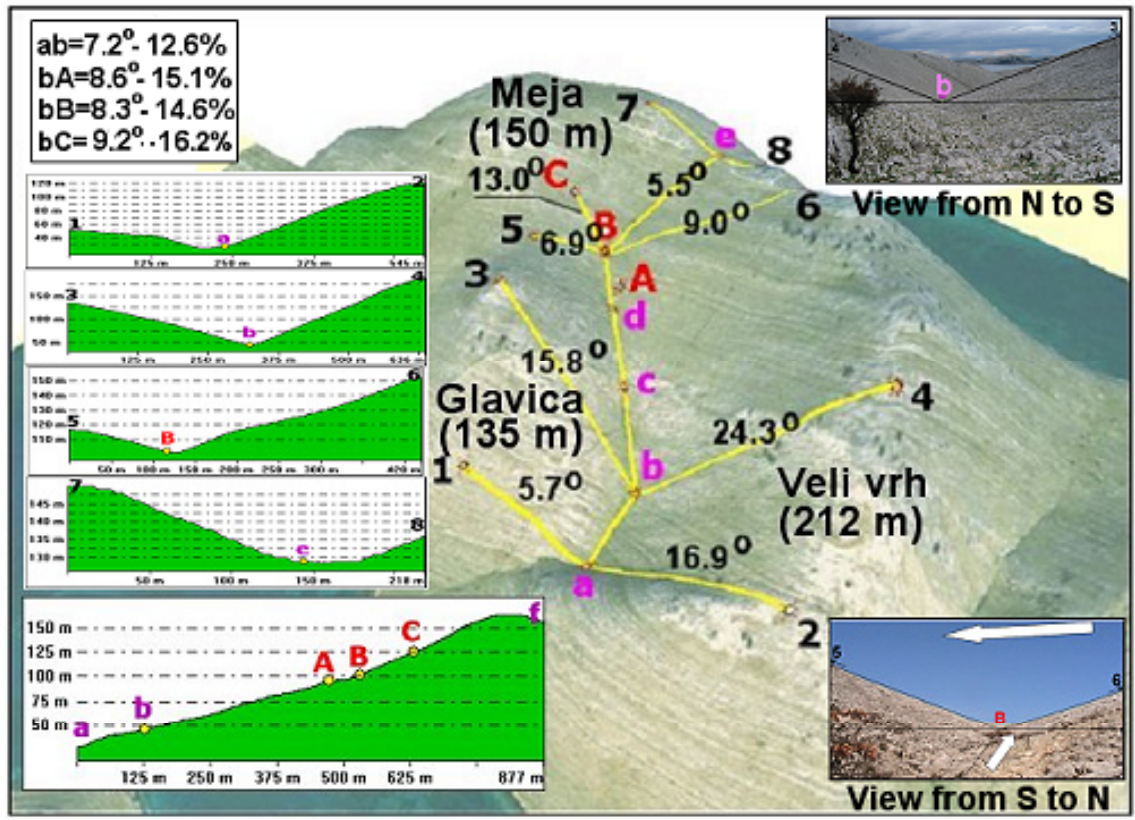

Figure 3: $\quad$ Sipnate canyon configuration with slope angles and canyon photos from north to south and vice versa.

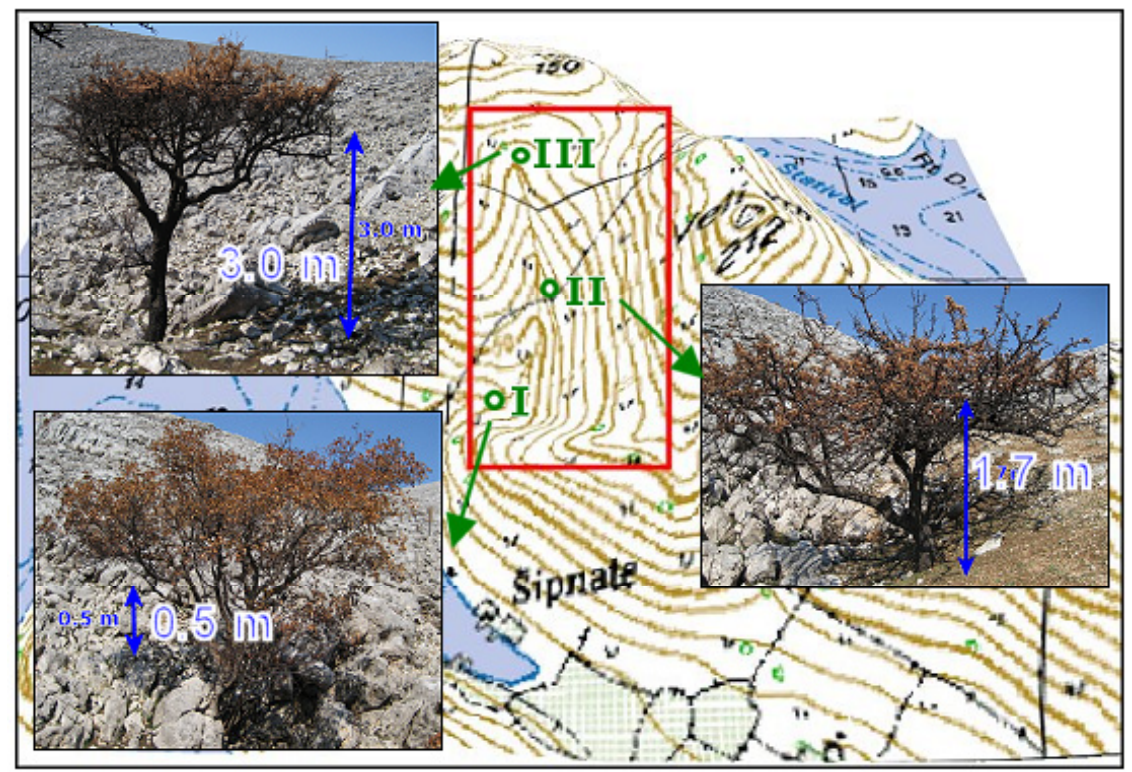

Figure 4: Unburned trees found on the line of canyon axis. 
recent research [1], all Kornati islands in fitogeographic sense belong to eumediterain vegetation zone with low and rare vegetation and rare olive-groves and vineyards located in small oases. According to vegetation card, on the biggest Kornat island, where accident happened, the vegetation association is of Stipo-salvietum officinalis $\mathrm{H}$-ic (1956) type, and sub association of Stiposalvietum officinalis var. Brachypodium ramosum. Vegetation species found on Kornat island are: Stipa bromoides (L.) Doerfler, Stipa pennata L., Poa bulbosa L., Poa sylvicola Guss., Koeleria splendens K. Presl, Brachypodium ramosum (L.) R.S., Euphorbia spinosa L., Onosma javorkae Simk., Cytisus spinescens Presl, Smilax aspera L., Rubus ulmifolius Schott, Salvia officinalis L., Pirus amygdaliformis Vill. (P. spinosa), Asparagus acutifolius L.

One month after the Kornati accident vegetation samples were collected at the unburned part of Glavica hill located on the west side of Šipnate canyon as fig. 5 shows, in order to test vegetation moisture, average fuel load, ignitability and flammability. The field sampling was performed during the similar wind and weather condition as it was on the date of accident. Vegetation ignitability and flammability was tested using the methodology described by Valette [2] based on standard quartz epiradiator measurements. The detailed vegetation analysis is presented in the paper by Španjol et al. [3].

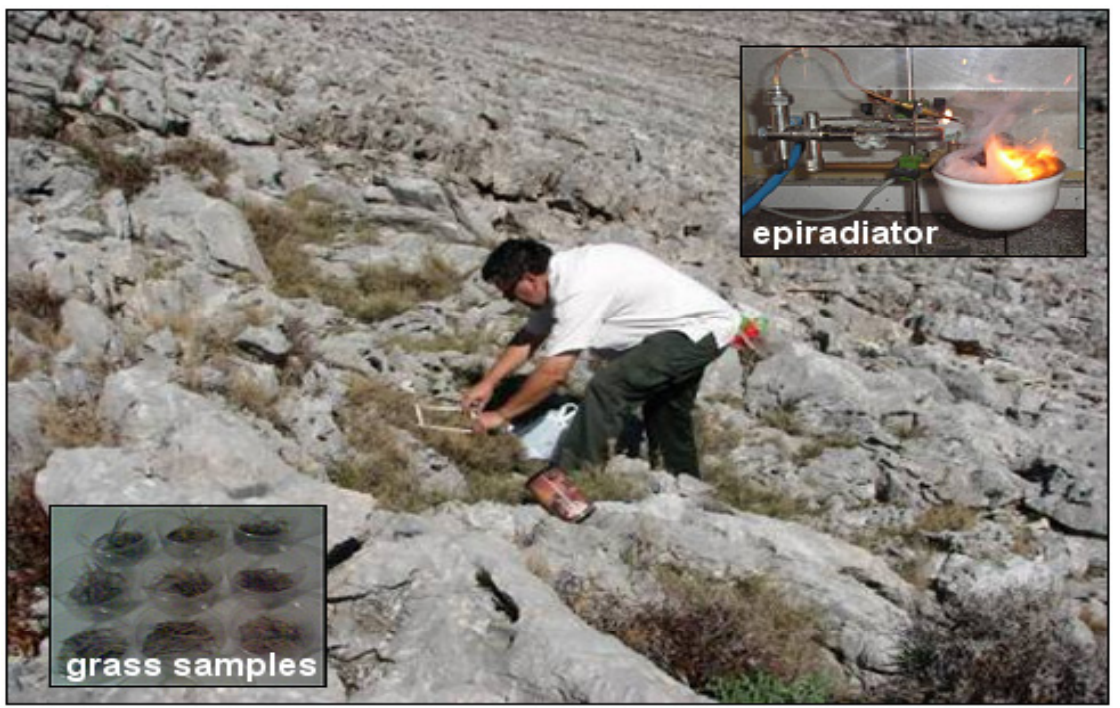

Figure 5: Field sampling on the unburned upper slopes of Glavica hill located on the west side of Šipnate canyon. The figure also shows grass samples and epiradiator used in the measurements.

Field sampling revealed that the shrubs were not burnt and that woody vegetation parts exceeding $5 \mathrm{~mm}$ in thickness remained vital and alive. The dry parts of grass vegetation sheltered by stones were also unaffected. Test results showed that the vegetation was extremely flammable. The humidity content of 
grass vegetation ranged from 10 to $16 \%$ and the ignition delay was $2 \mathrm{~s}$. In woody vegetation the ignition delay oscillated from 18 to $22 \mathrm{~s}$, with humidity ranging from 13 to $53 \%$. The average burning time of grass vegetation was $12 \mathrm{~s}$. The fuel load ranged from $5605-6851 \mathrm{~kg} /$ ha for $45 \%$ cover and from $6851-8373$ $\mathrm{kg} / \mathrm{ha}$ for $45 \%$ cover. The average vegetation heat content was estimated to 18 $000 \mathrm{~kJ} / \mathrm{kg}$. The total burned area in the bottom of Šipnate canyon was $99887 \mathrm{~m}^{2}$ (cca.10 ha).

Table 1: $\quad$ Vegetation fuel load in Šipnate canyon.

\begin{tabular}{|c|c|c|c|}
\hline \multirow{2}{*}{$\begin{array}{c}\text { Vegetation } \\
\text { Type }\end{array}$} & \multirow{2}{*}{$\begin{array}{c}\text { Percent } \\
(\%)\end{array}$} & \multicolumn{2}{|c|}{ Total cover } \\
\cline { 3 - 4 } & $\mathbf{4 5 \%}$ & $\mathbf{5 5 \%}$ \\
\hline woody & $\mathbf{3 5 \%}$ & $2180 \mathrm{~kg} / \mathrm{ha}$ & $2664 \mathrm{~kg} / \mathrm{ha}$ \\
\cline { 3 - 4 } vegetation & $\mathbf{4 5 \%}$ & $2803 \mathrm{~kg} / \mathrm{ha}$ & $3425 \mathrm{~kg} / \mathrm{ha}$ \\
\hline grass & $\mathbf{5 5 \%}$ & $3425 \mathrm{~kg} / \mathrm{ha}$ & $4187 \mathrm{~kg} / \mathrm{ha}$ \\
\cline { 2 - 4 } vegetation & $\mathbf{6 5} \%$ & $4048 \mathrm{~kg} / \mathrm{ha}$ & $4948 \mathrm{~kg} / \mathrm{ha}$ \\
\hline TOTAL & & $5605-6851 \mathrm{~kg} / \mathrm{ha}$ & $6851-8373 \mathrm{~kg} / \mathrm{ha}$ \\
\hline
\end{tabular}

\section{Meteorology}

Surface data from the Zadar and Velika Sestrica stations and upper-air data from the Zadar-Airport station as well as simulations of the vertical profiles of air temperature, wind speed and direction, developed by means of the ALADIN limited area numerical weather prediction model and the MM5 non-hydrostatic meso-model, were analysed at the time of the tragic fire on Kornat, on August 30th 2007. The detailed meteorological analysis is presented in the paper by Vučetić et al. [4].The surface data showed that, at $15 \mathrm{hrs}$, just before the passing of the cold front over the Zadar area, there was a shallow meso-cyclone which produced sultry, partly cloudy and windy weather, with moderate to strong jugo (SE wind). On a synoptic scale, the cyclone affected the whole Adriatic and the Apennine Peninsula with an accompanying $850 \mathrm{hPa}$ upper-level through affecting most of the west Mediterranean and the Adriatic Sea. Gusts of jugo exceeding $10 \mathrm{~m} / \mathrm{s}(36 \mathrm{~km} / \mathrm{h})$ were recorded in Zadar between 10 and $16 \mathrm{hrs}$ (fig. 6). According to data from the Vela Sestrica station, while the fire was raging, between 11 and $17 \mathrm{hrs}$, a $4 \mathrm{Bf}$ moderate jugo was blowing and the maximal air temperature reached $29.0^{\circ} \mathrm{C}$

The MM5 model simulations of the vertical structure of the atmosphere showed that the weather in the lower layers of the troposphere was favourable for the development and spread of the fire on Kornat, on August 30th 2007. The unstable stratification of the atmosphere boundary layer facilitated updrafts. A sudden increase in wind speed to $12-14 \mathrm{~m} / \mathrm{s}$ in the first 100-200 $\mathrm{m}$ height above the mean sea level, indicate the low-level jet stream with a very strong vertical wind shear in this layer (fig.7), whereas very high values of turbulent kinetic energy point at strong turbulence. Above this layer, a layer of temperature inversion was formed, about $300 \mathrm{~m}$ thick, preventing further updraft movements in the lower layer. In the inversion layer, wind speed rapidly decreased and the direction turned to $\mathrm{S}$. 


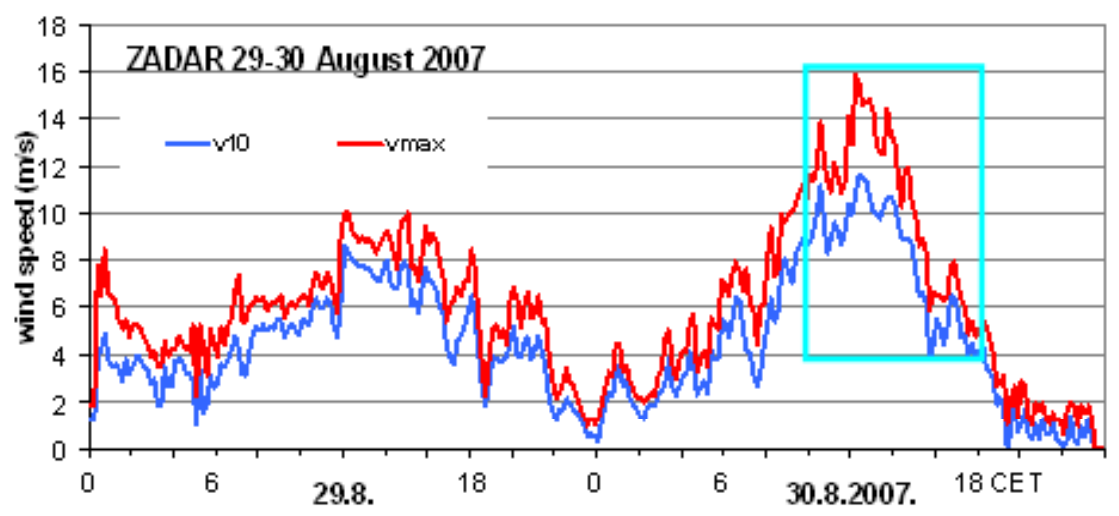

Figure 6: Diurnal cycles of mean 10-minute wind speed $\left(\mathrm{v}_{10}, \mathrm{~m} / \mathrm{s}\right)$ and maximal wind gust in the 10-minute interval $\left(\mathrm{v}_{\max }, \mathrm{m} / \mathrm{s}\right)$ for Zadar The rectangle marks the duration of the wildfire on the island of Kornat on August 30th 2007 from 10 to 17 CET.
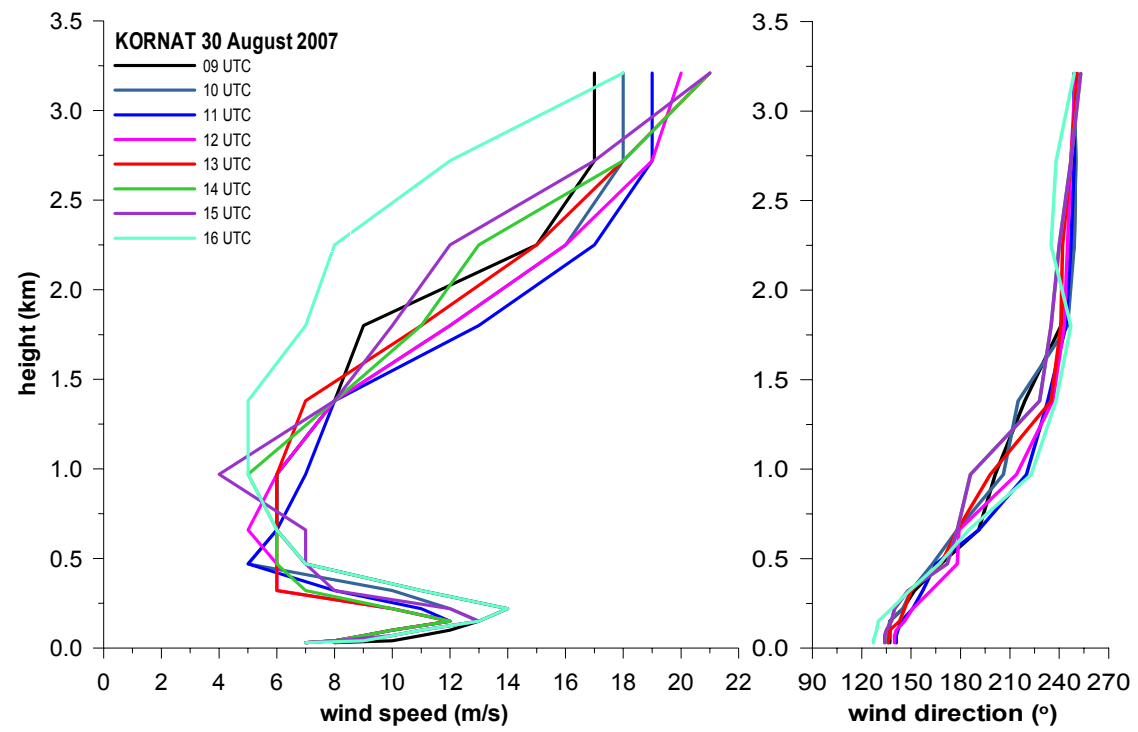

Figure 7: The vertical profile of wind speed $(\mathrm{m} / \mathrm{s})$ and direction $\left(^{\circ}\right)$ for the Kornat area up to $3 \mathrm{~km}$ defined by the MM5 model.

As the largest amount of humid air penetrated only up at $500 \mathrm{~m}$, strong convective cloud development did not take place on August 30th 2007. This paper shows for the first time in Croatia that two meteorological indicators low-level jet and approaching of a cold front - could point out the specific behaviour of a forest fire in the Šipnate canyon. 
In this analysis of the Canadian Forest Fire Weather Index System for the Zadar station it can be noted that the FWI (Fire Weather Index) and ISI (Initial Spread Index) values, in the period June 1st - September 12th 2007, reached their maximum precisely on August 30th 2007 (66.6 and 31.8, respectively). This means that during the whole of summer (and also from the beginning of the year) the FWI and ISI values in Zadar were not as high as they were on the day of the Kornat fire. The detailed analysis of Kornat forest fire is presented in [5]

For ISI values $>18$, in cases when high wood is on fire, the Canadian experts anticipate fire development in tree crowns and the creation of several fire fronts. In any case, this is an indication of the possibility of fire development with the worst possible consequences, including the not yet thoroughly researched or unknown effects generated by strong wind.

The FFMC (Fine Fuel Moisture Code) value on August 30th 2007 was 88.5, which would indicate a moisture content equal to $10-12 \%$ of the fine fuel mass. Unfortunately it was not possible to calculate the index values for the Vela Sestrica, Kukljica, Božava and other climatological stations located nearer to the Kornat island than the Zadar station nor the hourly and term (7, 14 and $21 \mathrm{~h}$ ) index values for August 30th 2007 to establish the part of the day when the indices reached their maximum. Therefore, it was not possible to present the spatial distribution of each index.

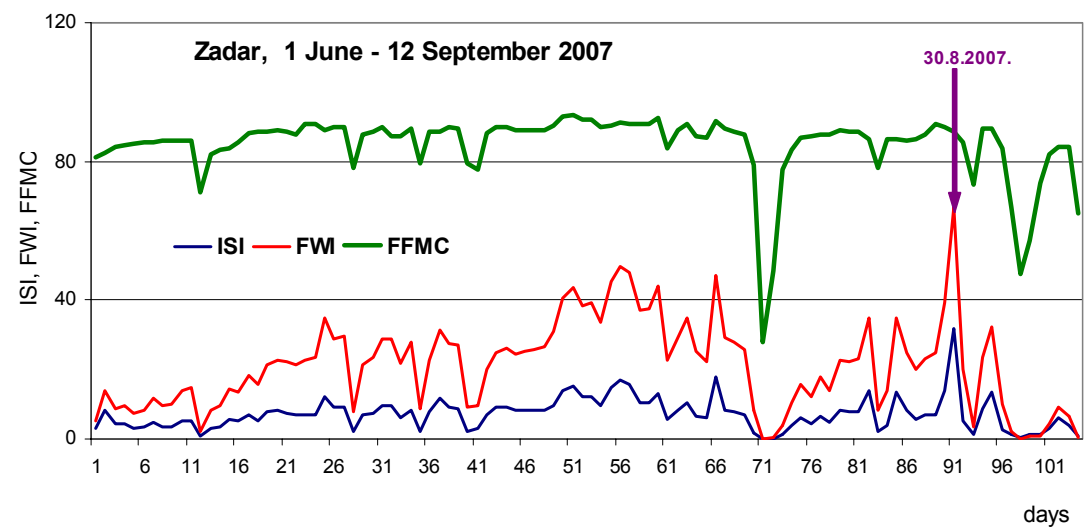

Figure 8: The daily course indices FWI (Fire Weather Index), ISI (Initial Spread Index) and FFMC (Fine Fuel Moisture Code) for the Zadar meteorological station, for June 1st-Sept 12th 2007 at 12 UTC.

Field observations on the Kornat island show that the fire developed on easily and quickly inflammable fuel (grass) and that the fire and hot air were rapidly carried by strong wind. Vegetation shows visible signs of the effect of the fire, the so-called mosaic, which appears in most instances of fire with strong wind along the Adriatic.

All observations on the Kornat island are subjective and performed without measuring instruments. For the field observations on Kornat and the ensuing 
preliminary analyses to gain credibility it is necessary to perform a reconstruction of the event and field meteorological measurements (on Kornat and the surrounding gorge) during jugo.

Table 2: $\quad$ Daily values of the air temperature $\left(\mathrm{t},{ }^{\circ} \mathrm{C}\right)$, relative humidity $(\mathrm{RV}$, $\%$ ), wind speed $(\mathrm{v}, \mathrm{m} / \mathrm{s})$, precipitation amount $(\mathrm{P}, \mathrm{mm})$ and indices of the FFMC (Fine Fuel Moisture Code), DMC (Duff Moisture Code), DC (Drought Code), ISI (Initial Spread Index), BUI (Buildup Index), FWI (Fire Weather Index), and DSR (Daily Severity Ratings) for the Zadar meteorological station during the period August 28th - September 2nd 2007 at 12 UTC.

\begin{tabular}{|c|c|c|c|c|c|c|c|c|c|c|c|}
\hline date & $\begin{array}{c}\mathbf{t} \\
{ }^{\circ} \mathrm{C}\end{array}$ & $\begin{array}{c}\mathbf{R H} \\
\%\end{array}$ & $\begin{array}{c}\mathbf{V} \\
\mathrm{m}\end{array}$ & $\begin{array}{c}\mathbf{P} \\
\mathrm{mm}\end{array}$ & $\begin{array}{c}\mathrm{FFM} \\
\mathrm{C}\end{array}$ & $\mathrm{DMC}$ & $\mathbf{D C}$ & ISI & BUI & FWI & DSR \\
\hline 28.8. & 32.1 & 41 & 2 & 0.0 & 90.7 & 59.1 & 651.1 & 7.2 & 96.3 & 24.8 & 7.9 \\
\hline 29.8. & 28.0 & 53 & 4 & 0.0 & 89.9 & 61.9 & 659.1 & 14.0 & 100.3 & 39.4 & 18.1 \\
\hline 30.8. & 28.3 & 61 & 6 & 0.0 & 88.5 & 64.3 & 667.2 & 31.8 & 103.6 & 66.6 & 45.9 \\
\hline 31.8. & 21.2 & 72 & 3 & 0.0 & 85.7 & 65.6 & 674.0 & 5.1 & 105.5 & 20.2 & 5.6 \\
\hline 1.9. & 28.3 & 42 & 2 & 11.1 & 73.4 & 35.6 & 604.3 & 1.1 & 62.0 & 3.7 & 0.3 \\
\hline 2.9. & 27.5 & 34 & 3 & 0.0 & 89.6 & 38.9 & 611.0 & 8.8 & 67.2 & 23.6 & 7.3 \\
\hline
\end{tabular}

Also, for all further research, it would be necessary to build a model of the gorge and carry out measurements and research in a controlled laboratory environment. Meteorological analyses of fire events in Croatia are not frequent. However, the unusual effects of fire in certain weather conditions on the islands and along the coast were noticed already ten years ago. This points to neglect of research and inadequate transfer of multidisciplinary knowledge and awareness to fire-fighters, who can meet extremely dangerous situations when putting out fires.

\section{Conclusions}

Šipnate canyon is small canyon long about $500 \mathrm{~m}$, closed from three sides (east, north and west) and opened only from the south. Average slope of the canyon axis is about $15 \%\left(9^{\circ}\right)$, and maximum slopes of its left and right sides are $29 \%$ $\left(16^{\circ}\right)$ and $45 \%\left(24^{\circ}\right)$ respectively. Total area of the burned canyon bottom was $99887 \mathrm{~m}^{2}$. Vegetation in Šipnate canyon was mostly grass with $35-45 \%$ of woody vegetation and total cover between $45-55 \%$. Vegetation was extremely flammable with ignition delay less than $2 \mathrm{~s}$. The fuel load ranged from $5605-8$ $373 \mathrm{~kg} / \mathrm{ha}$, and humidity content from 10 to $16 \%$. Meteorological situation shows that there was a shallow meso-cyclone over the Zadar area which produced sultry, partly cloudy and windy weather, with moderate to strong jugo (SE wind). The MM5 model simulations showed the low-level jet stream in the first 100-200 m height above the mean sea level. Above this layer, a layer of temperature inversion was formed, about $300 \mathrm{~m}$ thick, preventing further updraft movements in the lower layer. In this analysis of the Canadian Forest Fire Weather Index System for the Zadar station it can be noted that FWI and ISI reached their maximum precisely on August 30th 2007 (66.6 and 31.8, respectively). 
The aim of this paper is not only to give introduction to Kornati accident, describing the input data used in our other Kornati accident analyses, but also to encourage other researchers to perform their own, independent research trying to find the write answer to the question - What could happened on Kornati island on August 30th 2007 between 11:30 and 16:00 hrs ? Some possible explanations are given in papers and presentations [6-8].

\section{References}

[1] Trinajstić, I., Kornati islands vegetation, Proc. of conf. Prirodna podloga, zaštita, društveno i gospodarsko valoriziranje, 161-179, 1996 (in Croatian)

[2] Valette, J.C., Inflammabilites des especes forestieres MediterraneennesConsequences sur la combustibilite des formations forestieres. Rev. For. Fr. 42, 76-92, 1990

[3] Španjol Ž, Rosavec R., Barčić, D., Vegetation conditions and flammable material on the island of Kornati related to the Kornati fire on 30 August 2007, Croatian Meteorological Journal, 42, (in print in Croatian)

[4] Vučetić, V., Ivatek-Šahdan, S., Tudor, M., Kraljević, L., Ivančan-Picek B., Strelec Mahović, N., Weather Analysis during the Kornat Fire on 30 August 2007, Croatian Meteorological Journal, 42, (in print in Croatian)

[5] Vučetić, M., Meteorological Analysis of Kornat Fire Risk on 30 August 2007, Croatian Meteorological Journal, 42, (in print in Croatian)

[6] Klarin, B., Ninić, N., Stipaničev, D., Nižetić, S., Krstinić, D., The Kornati Fire Accident - Aerodynamics and Thermodynamics Aspects, Forest Fires 2008, Toledo (this conference)

[7] Viegas, D.X., Stipaničev, D., Ribeiro, L., Pita, L., Rossa, C., The Kornati Fire Accident - Eruptive Fire in Relatively Low Fuel Load Herbaceous Fuel Conditions?, Forest Fires 2008, Toledo (this conference)

[8] Workshop on Forest Fire Behaviour and Kornati Fire Accident - Facts and Preliminary Research Results, Feb. 4th 2008, Split, Croatia. http://laris.fesb.hr/Kornati-040208.htm 